\title{
Proximate Composition, Nutrient Mineral and Fatty Acid of the Bunchosia glandulifera Fruit
}

\author{
Daiane Einhardt Blank ${ }^{1}$, Sara Fraga ${ }^{1}$, Mariana Bellaver ${ }^{1}$, Carla Eliete Iochims dos Santos ${ }^{2}$, Johnny Ferraz Dias ${ }^{3}$, \\ Luiz Antônio Mendonça Alves da Costa ${ }^{4}$, Neusa Fernandes de Moura ${ }^{1, *}$ \\ ${ }^{1}$ Natural Products Research Group, Federal University of Rio Grande, Santo Antônio da Patrulha, Brazil \\ ${ }^{2}$ Physics, Statistics and Mathematics Institute, Federal University of Rio Grande, Santo Antônio da Patrulha, Brazil \\ ${ }^{3}$ Ion Implantation Laboratory, Federal University of Rio Grande do Sul; Porto Alegre, Brazil \\ ${ }^{4}$ Department of Chemistry, Federal University of Roraima, Boa Vista, RR, Brazil \\ *Corresponding author: nfmfurg@gmail.com
}

\begin{abstract}
Bunchosia glandulifera is an exotic species found in southern of Brazil, of which the pulp and toasted seed are much used because of their stimulating properties and nutritional values. However, few scientific data are reported about the chemical composition of the $B$. glandulifera fruit and the benefits its consumption. The aim of this study was to determine the fatty acid, proximate and mineral composition of the fruit. The results revealed that soluble solids and sugars are present at high concentration in the pulp, whereas the seed predominantly contained protein and ash. According to the particle-induced X-ray emission (PIXE) measurement, the elemental composition revealed that $\mathrm{K}, \mathrm{P}, \mathrm{Ca}$, and $\mathrm{Mg}$ are the most abundant minerals in the fruit. Interestingly, the ingestion of $200 \mathrm{~g}$ of the fruit provides $100 \%$ of the recommended daily ingestion (RDI) of some elements. Moreover, among the seventeen fatty acids found in the pulp and seed, palmitic acid (C16:0) was found to be the most concentrated.
\end{abstract}

Keywords: mineral analysis, proximate composition, fatty acid, Bunchosia glandulifera

Cite This Article: Daiane Einhardt Blank, Sara Fraga, Mariana Bellaver, Carla Eliete Iochims dos Santos, Johnny Ferraz Dias, Luiz Antônio Mendonça Alves da Costa, and Neusa Fernandes de Moura, "Proximate Composition, Nutrient Mineral and Fatty Acid of the Bunchosia glandulifera Fruit." Journal of Food and Nutrition Research, vol. 5, no. 7 (2017): 575-578. doi: 10.12691/jfnr-5-8-7.

\section{Introduction}

Fruits are important constituents of diet, providing energy, antioxidants and minerals, which are essential to the maintenance of several physiological functions. According the World Health Organization, the regular consumption of fruits is a determining factor for body maitenance in a healthy diet. It is estimated that low consumption of fruits and vegetables causes about 2.7 million deaths every year, thus being one of the top-10 risk factors contributing to mortality [1].

Among the huge variety of fruits found in Brazil, $B$. glandulifera is an exotic species that is cultivated at private residences or farms, mainly in the south of the country such as in the Santo Antonio da Patrulha region (29 50' 18" S, 50 30' 58" W). Popularly known as "guaraná, caferana, or falso-guaraná", the B. glandulifera fruit presents small size and red color when ripe [3]. The color is associated with the presence of carotenoids, which are bioactive compounds known to prevent prostate cancer and cardiovascular diseases. The main carotenoid present in the pulp of the $B$. glandulifera fruit is lycopene. In addition, the fruit is also rich in phenolic compounds totaling approximately $2.193 \mathrm{mg} / 100 \mathrm{~g}$, which is higher than the values found for most fruits [4].
According to the local population, the fruit possesses stimulating and nourishing properties, and its frequent consumption provides longevity, physical vigor, and mental clarity. These effects may be associated with the presence of caffeine in the pulp and seed of $B$. glandulifera at high concentration. The caffeine is a powerful stimulant of the central nervous system and, when consumed in adequate amounts, the consumer experiences reduced drowsiness and fatigue, and increased intellectual activity [4].

Knowledge of the elemental composition and nutritional factors of fruits is essential for the evaluation of consumption and development of new food products. A healthy diet should include minerals and lipids, which are important nutrients found in different types of fruits. A balanced intake of fatty acids is directly associated with cardiovascular disease prevention [2]. In addition, since minerals play important roles in several physiologic events, it is necessary to maintain a balanced mineral concentration to avoid diseases related to their excess or deficiency.

However, the literature contains only a few reports on B. glandulifera, which emphasizes the need for additional research on this species. Therefore, this study aimed to determine the elemental composition of $B$. glandulifera fruit using particle-induced X-ray emission (PIXE), and the fatty acid and proximate content using chemical approaches. 


\section{Material and Methods}

\subsection{Sample Collection}

B. glandulifera fruits were collected on January 2015 at Santo Antonio da Patrulha, a city located near the northeast seacoast of the Rio Grande do Sul state, Brazil. A voucher specimen was deposited in the Herbarium of the Federal University of Rio Grande do Sul (UFRGS), under the number 167276ICN with designation Bunchosia glandulifera (Jacq.) Kunth (Malphiguiaceae). After collection, fruits were washed with distilled water. Seed and pulp were separated and stored in polyethylene bags at $-18^{\circ} \mathrm{C}$ until proximal composition and fatty acid analysis. For PIXE analysis, pulp and seed were dried for approximately $5 \mathrm{~h}$ at $100^{\circ} \mathrm{C}$, macerated using mortar and pestle, and pressed into pellets.

\subsection{Proximal Composition}

The proximal composition analysis $(\mathrm{pH}$, ash, soluble solids, total sugars, lipids, moisture, reducing sugars, proteins, and fiber) was performed in triplicate and in accordance with the Analytical Standards Institute Adolfo Lutz [5]. The total carbohydrate content, including sugars and fiber, was determined using the equation Total carbohydrate $=100-$ (moisture + ash + proteins + lipids $)$. The total energy value was estimated using the water conversion values of $4 \mathrm{Kcal} / \mathrm{g}$ for protein and carbohydrates and $9 \mathrm{Kcal} / \mathrm{g}$ for lipids.

\subsection{Fatty Acid Composition}

The oil to fatty acid analysis was obtained using $20 \mathrm{~g}$ of pulp and seed samples, which subsequently suffered extraction with chloroform / methanol following method Bligh and Dyer [6].

Fatty acid methyl esters (FAMEs) were prepared by methylation, according to the methodology proposed by Joseph and Ackman [7]. In particular, $25 \mathrm{mg}$ of oil was added to $1.5 \mathrm{~mL}$ of $0.50 \mathrm{M} \mathrm{NaOH}$ in methanol and the mixture was heated in water bath at $100^{\circ} \mathrm{C}$ for $5 \mathrm{~min}$. Then, $2 \mathrm{~mL}$ of solution $\mathrm{BF}_{3}\left(14 \% \mathrm{BF}_{3}\right.$ in methanol) and heated in water bath at $100^{\circ} \mathrm{C}$ for $30 \mathrm{~min}$. After cooling, 1 $\mathrm{mL}$ of isooctane was added and the solution was slowly stirred for 30s. Then, $5 \mathrm{~mL}$ of saturated $\mathrm{NaCl}$ aqueous solution was added. The supernatant was transferred into a clean flask, $1 \mathrm{~mL}$ of isooctane was added and the resulting solution was stirred. The solvent was removed under nitrogen flow until a final volume of $1 \mathrm{~mL}$ was reached for chromatographic analysis.

FAMEs were separated using a Shimadzu gas chromatographer (model CG-2010) equipped with flame ionization detector (FID) and Omegawax 250 capillary column $(30 \times 0.25 \mathrm{~mm}$ i.d. $\times 0.25 \mu \mathrm{m})$. The gas flow rates were $1.2 \mathrm{~mL} / \mathrm{min}$ for $\mathrm{H}_{2}$ (carrier gas), $30 \mathrm{~mL} / \mathrm{min}$ for $\mathrm{N}_{2}$ (makeup gas), and 30 and $300 \mathrm{~mL} / \mathrm{min}$ for $\mathrm{H}_{2}$ and synthetic air (flame gases), respectively. Each sample (1 $\mu \mathrm{L})$ was automatically injected in triplicate, and the sample split rate was 1:50. The operational parameters were as follows: injection and detector temperatures were maintained at $250^{\circ} \mathrm{C}$ and $260^{\circ} \mathrm{C}$, respectively; initial column temperature of $50^{\circ} \mathrm{C}$ was increased to $220^{\circ} \mathrm{C}$ at a rate of $4^{\circ} \mathrm{C} / \mathrm{min}$. For fatty acid (FA) identification, the retention times were compared to those of FAME standards.

\subsection{PIXE Analysis}

PIXE consists in a multi-elemental technique based on the characteristic X-ray emission induced by an energetic ion beam, with enough limit of detection for the most part of minerals (about $1 \mathrm{ppm}$ ) [8,9]. All measurements were performed using a 2-MeV proton beam generated in a 3$\mathrm{MeV}$ electron accelerator. Samples were accommodated in a holder inside the PIXE reaction chamber, which was kept at a pressure of $10^{-6}$ mbar. Each sample was irradiated for $400 \mathrm{~s}$ using an average current of approximately $3 \mathrm{nA}$. The X-rays emitted from the samples were detected by a $\mathrm{Si}(\mathrm{Li})$ detector with an energy resolution of approximately $160 \mathrm{eV}$ at $5.9 \mathrm{keV}$. PIXE spectra were fitted using the GUPIXWIN software [10] and elemental concentrations were obtained. For PIXE standardization purposes, in this study, the apple leaves standard from the National Institute of Standards and Technology (NIST reference material 1515) was used.

\subsection{Statistical Analysis}

Statistical analysis of the elemental concentration consisted in performing the Student's $t$-test (SPSS version) with $5 \%$ significance level $(\mathrm{P}<0.05)$ to compare results obtained from seed and pulp.

\section{Results and Discussion}

Table 1 shows the proximate composition for the pulp and seed of the $B$. glandulifera fruit. According to the results, the pulp contains a higher concentration of total sugars and soluble solids than the seed does. Soluble solids are mainly constituted by sugars, which are important for fruit processing and make the fruit pulp the most appreciated part of the plant for consumption [11]. The seed contains a higher concentration of proteins and ash, which confer high nutritional value, than other parts of the plant. The pulp and seed of $B$. glandulifera exhibited total energetic values higher than $100 \mathrm{Kcal} / 100$ $\mathrm{g}$, which makes the fruit suitable for consumption in highcalorie diets.

Table 1. Proximate composition of the fruit pulp and seed of Bunchosia glandulifera

\begin{tabular}{lcc}
\hline & Pulp & Seed \\
\hline Moisture (\%) & $72.00^{\mathrm{a}} \pm 0,06$ & $55.00^{\mathrm{b}} \pm 0,55$ \\
Ash (\%) & $1.30^{\mathrm{b}} \pm 0,09$ & $2.90^{\mathrm{a}} \pm 0,04$ \\
Fat (\%) & $0.13^{\mathrm{b}} \pm 0,04$ & $0.30^{\mathrm{a}} \pm 0,07$ \\
Proteins\% & $2.45^{\mathrm{b}} \pm 0,09$ & $7.00^{\mathrm{a}} \pm 0,09$ \\
pH & $5.09^{\mathrm{b}} \pm 0,00$ & $8.12^{\mathrm{a}} \pm 0,02$ \\
Reducing sugars (\%) & $3.57 \pm 0,08$ & ---- \\
Total sugars (\%) & $6.25^{\mathrm{a}} \pm 0,09$ & $1.66^{\mathrm{b}} \pm 0,01$ \\
Soluble solids (\%) Brix) & $11.72^{\mathrm{a}} \pm 0,01$ & $4.52^{\mathrm{b}} \pm 0,04$ \\
Fiber (\%) & $0.43^{\mathrm{b}} \pm 0,01$ & $1.94^{\mathrm{a}} \pm 0,09$ \\
Total Carbohydrates (\%) & $24.12^{\mathrm{b}} \pm 0,02$ & $34.80^{\mathrm{a}} \pm 0,24$ \\
Total energetic value (Kcal/ 100g) & $107.45^{\mathrm{b}} \pm 0,05$ & $193.3^{\mathrm{a}} \pm 0,13$ \\
\hline
\end{tabular}

Values are for std deviations of carefully conducted triplicate experiments. Furthermore, mean carrying different superscripted alphabets vary $(\mathrm{p}<0.05)$ with $95 \%$ confidence. 
PIXE results showed that $K$ is the most abundant mineral in the pulp and seed of $B$. glandulifera fruit, since the seed has a higher concentration of $\mathrm{K}$ than the pulp. The consumption of $200 \mathrm{~g}$ of $B$. glandulifera fruit pulp provides $65.5 \%$ of the recommended daily ingestion (RDI) value $(4700 \mathrm{mg} / \mathrm{d})$, while the same amount of seed provides $86 \%$ of the RDI value.

Usually, fruits are rich in $\mathrm{K}$ because this element presents great mobility in plants. In addition, its low affinity for organic chelates explains why this metal is present at high concentration in vegetal tissues [12]. When associated with $\mathrm{Na}$ in humans, $\mathrm{K}$ plays a role in maintaining water balance and neural impulse transmission. Interestingly, the $\mathrm{K}$ level in the $B$. glandulifera fruit pulp is similar to that found in the pulp of Myrciaria cauliflora (jaboticaba) and M. cauliflora seed [12], whereas it is higher than that found in Citrus reticulata (tangerine) (599 mg/100 g) [13].

The fruit pulp and seed of B. glandulifera also contain $\mathrm{S}, \mathrm{P}, \mathrm{Ca}$, and $\mathrm{Mg}$ at high concentration, and the seed has a higher concentration of these minerals than the pulp. $\mathrm{P}$ concentration in the seed may be associated with the presence of phytin, a compound considered a reservoir of phosphorus during the germination period. $\mathrm{P}$ plays an important role in cell structure and many biochemical reactions such as energy metabolism [14]. $\mathrm{Mg}$ is associated with the green pigmentation of plants and is more concentrated in the seed than in other parts of the fruit [15]. Since the consumption of $200 \mathrm{~g}$ of the fruit pulp provides $57 \%$ of the RDI (260 mg/d) and the consumption of the same amount of seed provides $100 \%$ of the RDI value, the $B$. glandulifera fruit is an excellent source of this element.

Moreover, the results showed that the pulp showed higher concentration the $\mathrm{Fe}$ and $\mathrm{Al}$ than seed. The consumption of $200 \mathrm{~g}$ of the B. glandulifera pulp provides more than $100 \%$ of the $\mathrm{Al}$ and Fe RDI values. Despite its importance in several physiological process such as oxygen transportation in the muscles [16], Fe excess (average intake is $14 \mathrm{mg} / \mathrm{d}$ ) may be associated with oxidative stress, as well as $\mathrm{Al}$ excess (intake ranges from 0.3 to $3.6 \mathrm{mg} / \mathrm{d}$ ) is involved in bone phosphate mobilization, thus influencing ionic balance $[17,18]$.

The concentration of $\mathrm{Si}$ in the pulp of B. glandulifera was higher than in the seed and the estimated intake range of $10-25 \mathrm{mg} / \mathrm{d}$. Although Si is an important mineral in the production of collagen, its accumulation in animal tissues may be related to increased oxidative stress [19].

Others important macronutrient and micronutrients (e.g., $\mathrm{Zn}, \mathrm{Ca}$, and $\mathrm{Mn}$ ) were also detected in the B. glandulifera fruit whit higher concentration in the seed. This element participates in reactions involving the synthesis and degradation of secondary metabolites and nucleic acids. $\mathrm{Ca}, \mathrm{Zn}$, and $\mathrm{Mg}$ are required as cofactors in enzymatic processes and participate to the structure of the DNA self-repair system. [20]. Interestingly, 200 g B. glandulifera fruit provide more than $100 \%$ of the Mn RDI value (2.3 mg/day). Mn concentration in B. glandulifera fruit is similar to that found in other exotic fruit such as bacuri and ingá-açu [21].

Table 3 shows the fatty acid composition of the pulp and seed of the B. glandulifera fruit (Table 3). Thirteen fatty acids were found, including saturated fatty acid (SFA), monounsaturated fatty acid (MUFA), and polyunsaturated fatty acid (PUFA). The pulp showed higher fatty acids content than the seed did. In particular, palmitic acid (C16:0) was predominant. Among saturated fatty acids, palmitic acid is the most abundant in diets. Moreover, it is the main fatty acid (40\%) found in the palm oil (Elaeis guineensis) [22]. A previous study reported that this acid elevates plasma concentration of cholesterol and low-density lipoprotein (LDL) [2].

Another saturated fatty acid found at high concentration is stearic acid. The seed showed higher concentration this acid than the pulp. The stearic acid is rapidly metabolized to oleic acid, a monounsaturated fatty acid beneficial to humans [23].

Table 2. Elemental composition of Bunchosia glandulifera

\begin{tabular}{ccc}
\hline Mineral & Pulp & Seed \\
\hline Na & $5.37^{\mathrm{b}} \pm 1.00$ & $8.69^{\mathrm{a}} \pm 2.10$ \\
$\mathbf{M g}$ & $74.4^{\mathrm{a}} \pm 6.90$ & $152.41^{\mathrm{b}} \pm 31.00$ \\
$\mathbf{A l}$ & $16.66^{\mathrm{a}} \pm 5.90$ & $12.30^{\mathrm{b}} \pm 3.60$ \\
$\mathbf{S i}$ & $31.62^{\mathrm{a}} \pm 13.20$ & $9.71^{\mathrm{b}} \pm 2.30$ \\
$\mathbf{P}$ & $161.37^{\mathrm{a}} \pm 14.80$ & $364.81^{\mathrm{b}} \pm 73.20$ \\
$\mathbf{S}$ & $86.94^{\mathrm{a}} \pm 9.80$ & $181.96^{\mathrm{b}} \pm 35.00$ \\
$\mathbf{C l}$ & $32.79^{\mathrm{a}} \pm 2.10$ & $37.19^{\mathrm{a}} \pm 7.80$ \\
$\mathbf{K}$ & $1538.89^{\mathrm{a}} \pm 117.50$ & $2022.63^{\mathrm{b}} \pm 378.90$ \\
$\mathbf{C a}$ & $132.70^{\mathrm{a}} \pm 11.50$ & $207.96^{\mathrm{b}} \pm 40.00$ \\
$\mathbf{T i}$ & $0.41^{\mathrm{a}} \pm 0.01$ & $0.37^{\mathrm{a}} \pm 0.02$ \\
$\mathbf{C r}$ & $0.32^{\mathrm{a}} \pm 0.02$ & $0.25^{\mathrm{a}} \pm 0.08$ \\
$\mathbf{M n}$ & $1.03^{\mathrm{a}} \pm 0.20$ & $3.93^{\mathrm{b}} \pm 0.80$ \\
$\mathbf{F e}$ & $7.96^{\mathrm{a}} \pm 4.50$ & $5.72^{\mathrm{a}} \pm 2.60$ \\
$\mathbf{N i}$ & $0.55^{\mathrm{a}} \pm 0.47$ & $0.19^{\mathrm{b}} \pm 0.07$ \\
$\mathbf{C u}$ & $0.58^{\mathrm{a}} \pm 0.18$ & $0.55^{\mathrm{a}} \pm 0.15$ \\
$\mathbf{Z n}$ & $2.29^{\mathrm{a}} \pm 0.20$ & $4.01^{\mathrm{b}} \pm 0.80$ \\
$\mathbf{R b}$ & $2.82^{\mathrm{a}} \pm 0.90$ & $3.56^{\mathrm{b}} \pm 0.80$ \\
$\mathbf{S r}$ & $1.70^{\mathrm{a}} \pm 0.70$ & $1.39^{\mathrm{b}} \pm 0.20$ \\
\hline & &
\end{tabular}

Values are for std deviations of carefully conducted triplicate experimentsas mg/100 g,. Furthermore, mean carrying different superscripted alphabets vary $(\mathrm{p}<0.05)$ with $95 \%$ confidence.

Table 3. Fatty acid composition (\%) of the fruit pulp and seed of Bunchosia glandulifera

\begin{tabular}{lcc}
\hline Fatty acids & Pulp & Seed \\
\hline Lauric (C12:0 ) & 0.25 & - \\
Myristic (C14:0) & 1.23 & 0.67 \\
Myristoleic (C14:1) & 7.89 & 9.22 \\
Palmitic (C16:0) & 67.26 & 38.57 \\
Palmitoleic (C16:1) & 0.75 & 3.35 \\
Stearic (C18:0) & 7.40 & 13.28 \\
Oleic (C18:1, n-9) & 4.55 & 6.20 \\
Linoleic (C18:2, n-6) & 1.79 & 23.23 \\
Linolenic (C18:3, n-3) & 1.14 & - \\
Arachidonic (C20:0) & 0.72 & 1.80 \\
Behenic (C22:0) & 0.61 & 0.77 \\
Docosadienoic (C22:2) & 0.51 & - \\
Cerotic - C24:0 & 1.14 & - \\
SAF & 78,61 & 55.09 \\
MUFAS & 13.19 & 18.77 \\
PUFAS & 3.44 & 23.23 \\
Total & 95.24 & 97.09 \\
\hline
\end{tabular}


The amount of unsaturated fatty acids is higher in the seed than in the fruit pulp. Linoleic acid is the PUFA found at the highest concentration (69.69 mg/100 g fruit) in the seed of $B$. glandulifera. Ingestion of this acid is crucial to human because it cannot be produced by our metabolism. PUFAs reduce total cholesterol and LDL levels in plasma, induce lipid oxidation, and elevate HDL levels when consumed in large quantities, which contributes to the prevention of cardiovascular diseases [24].

\section{Conclusion}

According the authors' knowledge, this study reports for the first time on the fatty acids, proximal, and elemental composition of the $B$. glandulifera fruit. The fruit exhibited high value energy and rich in minerals. The seed had a higher concentration of minerals and PUFAs. This study revealed that the $B$. glandulifera fruit is an excellent source of essential macronutrients and micronutrients for human consumption.

\section{Acknowledgments}

We thank CAPES (Coordenação de Aperfeiçoamento de Pessoal de Nível Superior) for financial support.

\section{References}

[1] WHO, World Health Organization. The world health report. 2002. Reducing risks, promoting healthy life. Geneva.

[2] Lottenberg, A.M.P., "Importance of the dietary fat on the prevention and control of metabolic disturbances and cardiovascular disease", Arquivos Brasileiros de Endocrinologia \& Metabologia, 53: 595. Jun 2009.

[3] Anderson, W.R. Malpighiaceae (Malpighia Family). Memoirs of The New York Botanical Garden, New York 412-414. 2002.

[4] Silva, S.F., Blank, D.E., Peixoto, C.R., Moreira, J.J.S., Moura, N.F., "Bioactive Compounds and Antioxidant Activity of Bunchosia glandulífera”, International Journal Food Properties, 19: 467-473. Jun 2016

[5] IAL. Institute Adolfo Lutz. Methods for chemical and physical analysis of food, 4th edn. Analytical Standards of the Institute Adolfo Lutz, São Paulo. 2008.

[6] Bligh, E.G., Dyer, W.J., "A rapid method of total lipid extraction and purification”, Canadian Journal Biochemistry and Physiology, 37: 911-917. August 1959

[7] Joseph, J.D., Ackman., R.G., “Capillary column gas chromatographic method for analysis of encapsulated fish oils and fish oil ethyl esters”, Journal of AOAC International , 25: 488. May 1992.
[8] Johansson, S.A.E., Campbell, J.L., Malmqvist, K.G. ParticleInduced X-ray Emission Spectrometry (PIXE). JohnWiley, New York. 1995.

[9] Santos, C.E.I., Silva, L.R.M., Boufleur, L.A., Debastiani, R., Stefenon. C.A., Amaral, L., Yoneama, M.L., Dias, J.F., "Elemental characterisation of cabernet sauvignon wines using Particle-Induced X-ray Emission (PIXE)”, Food Chemistry, 121: 244-250. July 2010.

[10] Campbell, J.L., Boyd, N.I., Grassi, N., Bonnick, P., Maxwell. J.A. Nuclear Instruments and Methods in Physics Research Section B, 268: 3356. 2010.

[11] Santos, M.B., Cardoso, R.L., Fonseca, A.A.O., Conceição, M.N., "Caracterização e qualidade de frutos de umbu-cajá (Spondias tuberosa X S. mombin) provenientes do recôncavo sul da Bahia”, Revista Brasileira de Fruticultura, 32: 1089-1097. Dec 2010.

[12] Lima, A.J.B., Corrêa, A.D., Dantas-Barros, A.M., Nelson, D.L., Amorim, A.C.L., "Sugars, organic acids, minerals and lipids in jabuticaba”, Revista Brasileira de Fruticultura , 33: 540-550. Jun 2011.

[13] Gondim, J.A.M., Moura, M.F.V., Dantas, A.S., Medeiros, R.L., Santos, K.M., "Composição centesimal e de minerais em cascas de frutas”, Ciência e Tecnologia de Alimentos, 25: 825. Oct 2005.

[14] Mengel, K. and Kirkby, E.A. Principles of plant nutrition, 4th edn. International Potash Institute, Bern. 1987.

[15] Cordova, A., Navas, F.J., "Los radicales libres y el daño muscular producido por el ejercicio. Papel de los antioxidantes”, Arch Med Deporte, 76:169-75. Oct 2000.

[16] Konczak, I., Roulle, P., "Nutritional properties of commercially grown native Australian fruits: Lipophilic antioxidants and minerals”, Food Research International, 44, 2339-2344. August 2011.

[17] Fimreite, N., Hansen, O.O., Pettersen, H.C., "Aluminum Concentrations in Selected Foods Prepared in Aluminum Cookware and Its Implications for Human Health”, Bulletin of Environmental Contamination and Toxicology, 58: 1-7. Jan 1997.

[18] Oniwanwa, P.C., Ikadeh, G.C., Nwenze, S.E., "Aluminium contents of some raw and processed Nigerian foods", Food Chemistry, 58: 351-353. April 1997.

[19] Robberecht, H., Van Cauwenbergh, R., Van Vlaslaer, V., Hermans, N., "Dietary silicon intake in Belgium: Sources, availability from foods, and human serum levels", Science of the Total Environment, 407: 4777. May 2009.

[20] Fenech, M., "The Genome Health Clinic and Genome Health Nutrigenomics concepts: diagnosis and nutritional treatment of genome and epigenome damage on an individual basis", Mutagenesis, 20: 255-69. Jun 2005.

[21] Berto, A., Silva, A.F., Visentainer, J.V., Matsushita, M., Souza, N.E., "Proximate compositions, mineral contents and fatty acid compositions of native Amazonian fruits", Food Research International, 77: 441-449. November 2015.

[22] Sales, A.L.C. Synthesis, characterization and thermal analysis of the lithium, sodium and potassium salts of palmitic acid and its ethyl ester. Síntese, Mestrado em Ciências, USP, São Paulo. 2006.

[23] Castro, H.F., Mendes, A.A., Santos, J.C., Aguiar, C.L., "Modificação de óleos e gorduras por biotransformação", Química Nova, 27: 146. Feb 2004.

[24] Cho, K.H., Hong, J.H., Lee, K.T., "Monoacylglycerol (MAG)oleic acid has stronger antioxidant, anti-atherosclerotic, and protein glycation inhibitory activities than MAG-palmitic acid", Journal of Medicinal Food, 13: 99-107. Feb 2010. 